challenges faced by HCWs in battling the disease, is as equally important as effective political leadership in this time of global crisis-not only for the men and women in the frontline of the war against this pathogen but also, by extension, for the wellbeing of society at large.

Acknowledgment. We are indebted to James R. Valera for his assistance in editing the manuscript.

Financial support. No financial support was provided relevant to this article.

Conflicts of interest. All authors report no conflicts of interest relevant to this article.

\section{References}

1. Eighteen trainee doctors at Tokyo hospital infected with coronavirus after party. The Japan Times website. https://www.japantimes.co.jp/news/2020/ 04/07/national/science-health/18-trainee-doctors-keio-university-hospitaltokyo-coronavirus/\#.XqLqAC9h21s. Published April 7, 2020. Accessed April 23, 2020.
2. Discrimination of healthcare workers due to coronavirus 'disgraceful.' Channels News Asia (CNA) website. https://www.channelnewsasia.com/ news/singapore/wuhan-virus-coronavirus-covid19-discrimination-healthcareworker-12426528. Published February 12, 2020. Accessed April 23, 2020.

3. Covid-19 and the discrimination of medical personnel in the Philippines. Italian Institute for International Political Studies website. https:// www.ispionline.it/en/pubblicazione/covid-19-and-discrimination-medicalpersonnel-philippines-25725. Published April 8, 2020. Accessed April 22, 2020.

4. Hobson J, McMahon S. Asian-American doctor on experiencing racism during the coronavirus pandemic, feeling 'powerless' in helping patients. WBUR website. https://www.wbur.org/hereandnow/2020/04/20/asian-american-doctor-racismcoronavirus. Published April 20 2020. Accessed April 27, 2020.

5. Zhan M, Qin Y, Xue X, Zhu S. Death from Covid-19 of 23 Health Care Workers in China. N Engl J Med 2020 Apr 15 [Epub ahead of print]. doi: 10.1056/NEJMc2005696.

6. Klompas M, Morris CA, Sinclair J, Pearson M, Shenoy ES. Universal masking in hospitals in the covid-19 era. N Engl J Med 2020;382:e63. 2doi: 10.1056/ NEJMp2006372.

\title{
Deaths from COVID-19 in healthcare workers in Italy-What can we learn?
}

\author{
Pierfrancesco Lapolla ${ }^{1}$ (1), Andrea Mingoli MD, FACS ${ }^{1}$ (1) and Regent Lee DPhil, FRCS ${ }^{2}$ (1) \\ ${ }^{1}$ Department of Surgery P. Valdoni, Policlinico Umberto I, Sapienza University of Rome, Rome, Italy and ${ }^{2}$ Nuffield Department of Surgical Sciences, University of \\ Oxford, Oxford, United Kingdom
}

To the Editor-The novel coronavirus disease (COVID-19) pandemic is imposing a significant burden on healthcare systems worldwide. On April 16, 2020, the Italian National Institute of Health (ISS) reported that 16,991 healthcare workers (HCWs) had tested positive for severe acute respiratory syndrome coronavirus 2 (SARS-CoV-2). These HCWs had a median age of 48 years, and $68 \%$ were female and $32 \%$ were male, which is in line with the ratio in the Italian healthcare system $(66.8 \%$ female and $33.2 \%$ male). ${ }^{1,2}$ The infected HCWs accounted for $10.7 \%$ of the total number of positive cases $(n=168,941) .{ }^{1}$

Since the first case in the outbreak on February 21, the number of HCW deaths has risen dramatically. On April 17 the latest estimate of medical doctor deaths reached 119 , which is $57.8 \%$ of total HCW deaths; followed by nurses $16.5 \%(\mathrm{n}=34)$, nurse aides $8.3 \%$ $(\mathrm{n}=17)$ and dentists $5.8 \%(\mathrm{n}=12)$ (Fig. 1). ${ }^{3}$ The COVID-19related deaths include 2 nurses who committed suicide due to unsustainable pressure at work. ${ }^{4}$ No other country has seen the same elevated number of doctor deaths; China, where the epidemic began in December, had fewer. ${ }^{5}$ General practitioners seem to be the worst hit among all medical specialties, registering $32 \%$ deaths $(\mathrm{n}=66)$ (Fig. 1). ${ }^{3}$ This high rate could reflect their presence in the first line of defense for anyone presenting with the initial symptoms.

Author for correspondence: Pierfrancesco Lapolla, E-mail: lapolla.1526391@studenti. uniromal.it

Cite this article: Lapolla P, Mingoli A, and Lee R. (2021). Deaths from COVID-19 in healthcare workers in Italy -What can we learn?. Infection Control \& Hospital Epidemiology, 42: 364-365, https://doi.org/10.1017/ice.2020.241
Data available from the ISS on confirmed cases and deaths by age distribution indicate that $34 \%$ of the total HCWs testing positive $(n=16,953)$ were aged $50-59$ years and that $28.2 \%$ were aged $40-49$ years. Of HCW deaths, $43.3 \%$ were aged $60-69$ years and $26.7 \%$ were aged $50-59$ years. HCWs aged $70-79$ years comprised $20 \%$ of HCW deaths ( $12.6 \%$ case fatality rate). ${ }^{1}$

On April 9, 2020, the ISS ran a retrospective epidemiological analysis of the number of infected HCWs by category, care context, and site where the infection presumably occurred, together with type of activity carried out at the time of infection. These data are available for 16,179 of the 16,991 HCWs confirmed positive for the virus. Nurses and midwives together are the most represented with $43.2 \%(n=6,988)$ of all infected HCWs, followed by doctors $22 \%(n=3,574)$ divided between hospital doctors $19 \%(\mathrm{n}=3,071)$, general practitioners $0.8 \%(\mathrm{n}=130)$ and other doctors $2.3 \%(\mathrm{n}=373) .{ }^{1}$ Data for the healthcare context in which the infections presumably occurred are available for $11,738 \mathrm{HCWs}$; of these, $70.9 \%$ have contracted COVID-19 while serving in hospitals or in emergency care services (ambulance assistance). ${ }^{1}$

Interestingly, according to the National Federation of Orders of Surgeons and Dentists (FNOMCeO) registry, ${ }^{2}$ general practitioners accounted for the highest number of HCW deaths (Fig. 1) despite being the least infected group (as reported in the latest ISS analysis). ${ }^{1}$ Furthermore, according to the National Federation of Professional Nursing Orders (FNOPI), 32\% of the nurse deaths by April 16, 2020, initially contracted the virus while on duty in nursing care homes where personal protective

(c) 2020 by The Society for Healthcare Epidemiology of America. All rights reserved. This is an Open Access article, distributed under the terms of the Creative Commons Attribution licence (http://creativecommons.org/licenses/by/4.0/), which permits unrestricted re-use, distribution, and reproduction in any medium, provided the original work is properly cited. 


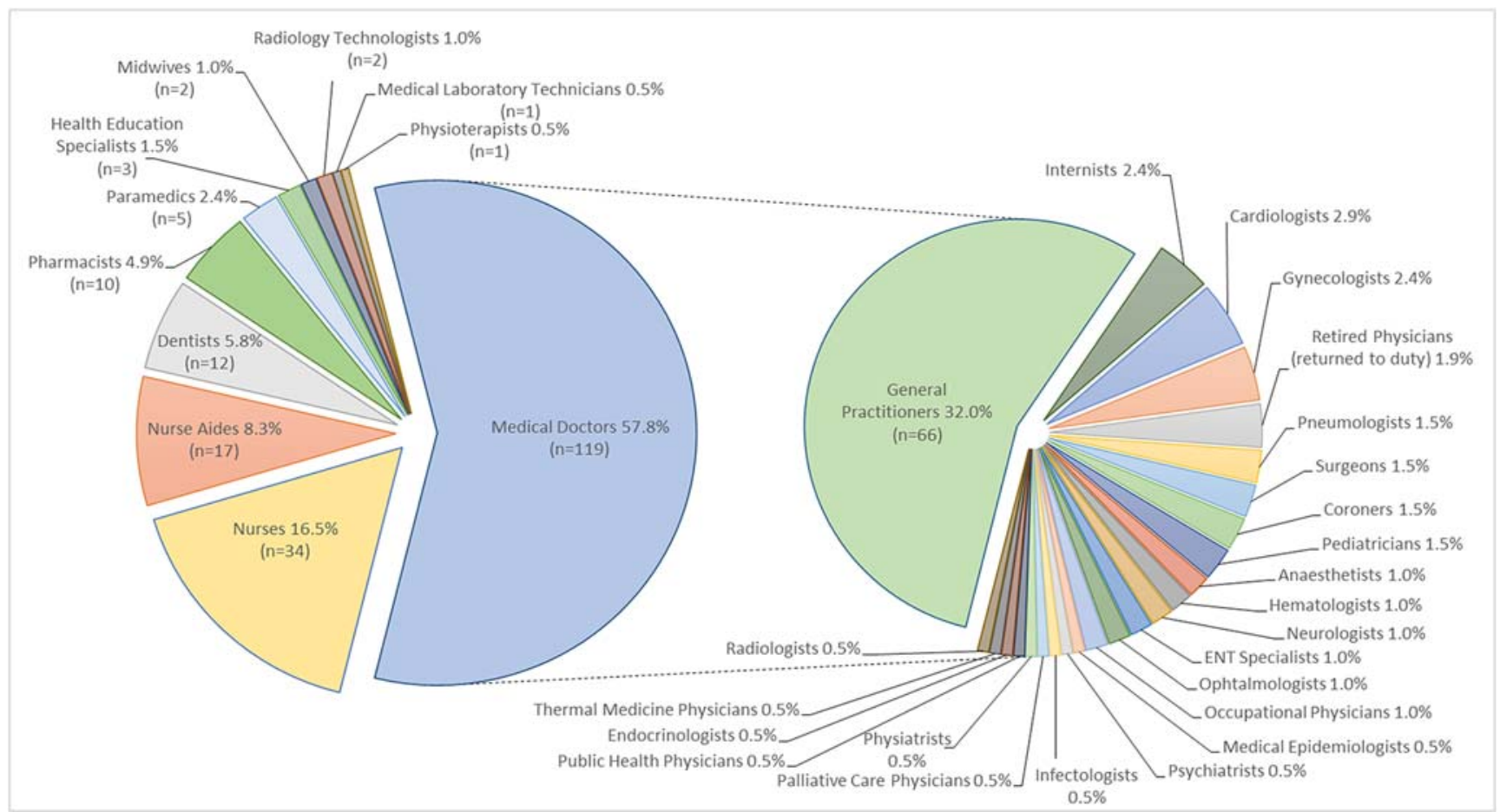

Fig. 1. Healthcare worker deaths from COVID-19 outbreak in Italy by category and medical specialty. ${ }^{\star}$

* Latest data are from the Italian National Federation of Orders of Surgeons and Dentists (FNOMCeO), the National Federation of Professional Nursing Orders (FNOPI), Italian Federation of Pharmacists (FOFI), National Federation of Medical Radiology Technicians, Technical Health Professions, Rehabilitation and Prevention Orders (FNO-TSRM-PSTRP), National Federation of Health and Social Health Professions (MIGEP). Data accessed April 172020.

equipment (PPE) was mostly lacking, and 50\% were working in nonhospital healthcare facilities. ${ }^{4}$

The sheer intensity of the COVID-19 outbreak in Italy, the recruitment of elderly retired doctors and shortages of PPE, particularly in nonhospital care, might be among relevant factors contributing to the elevated number of fatalities among HCWs in this country. Therefore, it is essential to carry out another retrospective epidemiological investigation and a prospective study to identify the main risk factors contributing to COVID-19-related deaths in the different HCWs categories in order to produce viable schemes for their protection. At this point, what lesson can other countries learn from the Italian sacrifice? Protecting and testing HCWs must be a top priority; governments will not be forgiven for needless deaths.

\section{Acknowledgments. None.}

Financial support. No financial support was provided relevant to this article.
Conflicts of interest. All authors report no conflicts of interest relevant to this article.

\section{References}

1. COVID-19 integrated surveillance: key national data. COVID-19 epidemic. 16 April 2020 national update. (In Italian). Italian National Institute of Health (ISS) website. https://www.epicentro.iss.it/coronavirus/sars-cov-2sorveglianza-dati. Published April 16, 2020. Accessed April 17, 2020.

2. Italian Ministry of Health. National healthcare staff, 2017 data [in Italian]. Italian Ministry of Health website. http://www.salute.gov.it/portale/news/ p3_2_1_1_1.jsp?lingua=italiano\&menu=notizie\&p=dalministero\&id=3845. Published July 31, 2019. Accessed April 17, 2020.

3. Registry of doctor deaths during COVID-19 epidemic [in Italian]. Italian National Federation of Orders of Surgeons and Dentists (FNOMCeO) website. https://portale.fnomceo.it/elenco-dei-medici-caduti-nel-corso-dellepidemiadi-covid-19/. Updated May 15, 2020. Accessed May 15, 2020.

4. National Federation of Professional Nursing Orders (FNOPI) website [in Italian]. https://www.fnopi.it/ Accessed April 17, 2020.

5. Zhan M, Qin Y, Xue X, et al. Death from Covid-19 of 23 healthcare workers in China. N Engl J Med 2020 Apr 15. doi: 10.1056/NEJMc2005696. 